\title{
ANALISIS PERBADINGAN KINERJA KEUANGAN DAN ABNORMAL RETURN SEBELUM DAN SESDUAH AKUISISI PADA PERUSAHAAN YANG TERDAFTAR DI BURSA EFEK INDONESIA TAHUN 2014
}

\author{
Ulfa Sakinah $^{1}$, Adhisyahfitri Evalina Ikhsan ${ }^{* 2}$ \\ ${ }^{1,2}$ Program Studi Akuntansi Fakultas Ekonomi dan Bisnis Universitas Syiah Kuala \\ e-mail: ulfasakinah07@yahoo.com ${ }^{1}$, adhisyahfitri.evalina@ unsyiah.ac.id $^{2}$ \\ * Corresponding Author
}

\begin{abstract}
Abstrak
The purpose of this study was to see a comparison of financial performance and abnormal return of companies before and after the acquisition of companies listed on the Stock Exchange in 2014. The number of samples used in this study were 10 companies, with a purposive sampling approach. The analysis technique used was paired sample $t$ test and Wilcoxon signed rank test. The variables used are return on equity, current ratio, debt to equity ratio, total asset turn over, earnings per share, and abnormal return. Testing the hypothesis in this study using the sample t-test and Wilcoxon signed ranks test. The results of this study indicate that there are differences in the ratio of total asset turn over, while the return on equity ratio, current ratio, debt to equity ratio, earnings per share, and abnormal return there are no significant differences between before and after the company makes an acquisition.
\end{abstract}

Keywords: return on equity, current ratio, debt to equity ratio, total asset turn over, earning per share, abnormal return, acquisition

\section{Pendahuluan}

Pasar modal merupakan tempat bagi perusahaan untuk menghimpun dana yang berfungsi untuk membiayai secara langsung kegiatan perusahaan. Berkembangnya teknologi dan informasi pada era globalisasi saat ini perusahaan dituntut melakukan berbagai macam usaha agar dapat mempertahankan eksistensi dan mengembangkan perusahaannya. Usaha ini dilakukan agar adanya pertumbuhan bisnis perusahaan guna mencapai tujuan jangka panjang perusahaan, memperbesar aset dan menguasai pasar.

Menghadapi berbagai tantangan perkembangan pasar modal dengan tuntutannya dalam persaingan untuk mempertahankan posisi ataupun keunggulan suatu perusahaan, berbagai langkah strategis perlu dilakukan dengan tepat. Perusahaan dapat memanfaatkan strategi konsentrasi atau diversifikasi melalui pengembangan internal produk dan jasa baru, ataupun melalui akusisi eksternal, merger, serta usaha bersama untuk meningatkan pertumbuhan bisnis (Hunger dan Wheelen, 2012:214). Salah satu ekspansi usaha yang sering dilakukan perusahaan yaitu akuisisi. Menurut Moin (2010:8) akuisisi dalam terminologi bisnis diartikan sebagai pengambilalihan kepemilikan atau pengendalian atas saham beserta aset suatu perusahaan oleh perusahaan lain, dan dalam peristiwa akuisisi baik perusahaan pengambilalih atau yang diambil alih tetap eksis sebagai badan hukum yang terpisah. Akuisisi dilakukan dengan membeli seluruh atau sebagian kepemilikan suatu perusahaan, dimana perusahaan pengakuisisi merupakan perusahaan yang mempunyai hak kontrol atas perusahaan target.

Di Indonesia sendiri aksi merger dan akuisisi terus berkembang. Merujuk riset Duff dan Phelps, nilai merger dan akuisisi di Indonesia mencapai US\$ 4 miliar pada semester I 2017, atau melonjak dua kali lipat dari periode yang sama tahun lalu. Transaksi terbesar terjadi pada Tencent Holdings senilai US\$ 1,2 miliar di Unicorn Go-Jek (www.kontan.co.id, diakses pada tahun 2017). Pada tahun 2018 kuartal I aksi merger dan akuisisi global cukup besar dimana nilai transaksinya meningkat 67 persen dari tahun sebelumnya. Nilai aksi merger dan akuisisi mencapai USD 1,2 triliiun atau sekitar Rp 16.503 triliun jika diasumsikan nilai kurs mata uang Rp 13.752 per dolar Amerika Serikat. Transaksi akuisisi paling besar yang terjadi di kuartal 12018 yaitu pengakuisisian jaringan farmasi AS Express Scripts Holding CO oleh asuransi 
kesehatan AS Cigna Corp senilai USD 67 miliar atau sekitar Rp 921,46 triliun. Selain itu, perusahaan Jerman E.ON SE akuisisi bisnis energi terbaru RWE AG senilai USD 38,5 miliar atau sekitar Rp 529,49 triliun (www.liputan6.com, diakses tahun 2018).

Menurut laporan tahunan KPPU kegiatan akuisisi di Indonesia terus meningkat. Pada tahun 2010 jumlah perusahaan yang melakukan akuisisi yaitu 3 perusahaan, kemudian terus meningkat hingga 90 perusahaan di tahun 2017.

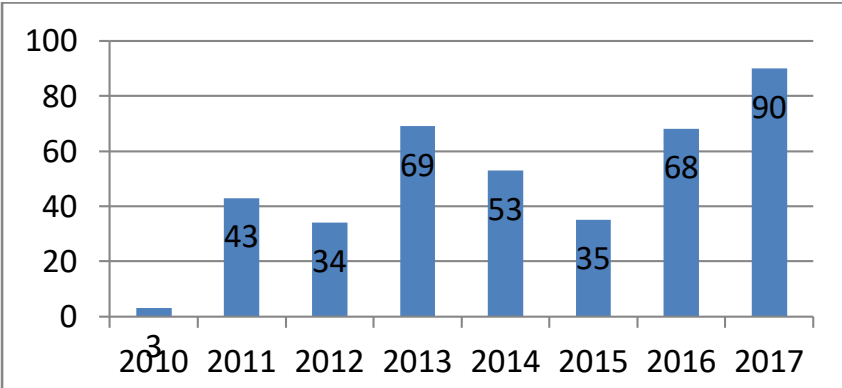

Sumber: Laporan Tahunan KPPU

Gambar 1.1

Grafik Notifikasi Akuisisi 2010-2017

Aktivitas akuisisi yang dilakukan perusahaan dianggap memiliki nilai positif dan mempengaruhi kinerja perusahaan dimana dapat berpotensi mendongkrak laba. Perubahan yang dialami oleh perusahaan setelah akuisisi akan nampak pada penampilan finansialnya. Ini sesuai dengan dasar logika dalam pengukuran akuntansi, jika skala aktivitas perusahaan meningkat ditambah dengan sinergi yang dihasilkan dari penggabungan aktivitas, maka seharusnya laba juga meningkat (Gusnita, 2017). Sehingga perusahaan setelah melakukan akuisisi seharusnya semakin membaik jika dibandingkan dengan sebelum akuisisi. Keberhasilan akuisisi yang dilakukan perusahaan dapat dinilai dengan melihat kinerja perusahaan. Kinerja keuangan dapat dianalisa pada laporan keuangan yang dilaporkan secara periodik, kemudian diukur dengan rasio-rasio keuangan, yang mana setiap rasio memiliki analisis yang berbeda. Adapun rasio keuangan tersebut yang akan digunakan dalam penelitian ini ada lima yaitu profitabilitas, likuiditas, leverage, aktivitas, dan rasio pasar.

Selain itu untuk menilai kinerja ekonomi perusahaan pasca akuisisi dapat juga diukur dengan melacak harga saham terhadap reaksi pasar secara keseluruhan. Febyanti (2014) pengumuman akuisisi merupakan alat komunikasi kepada pasar mengenai kinerja suatu perusahaan. Pengumuman kegiatan akuisisi perusahaan mengandung informasi penting. Peristiwa ini merupakan salah satu informasi yang diserap dan digunakan oleh investor untuk memperoleh keuntungan di masa yang akan datang. Informasi pengumuman akuisisi dapat diartikan secara positif dan negative oleh investor, yang dapat diukur melalui abnormal return yang mereka terima. Hasil dari abnormal return juga akan mengindikasikan Jika abnormal return positif berarti menunjukkan adanya peningkatan kemakmuran pemegang saham, dan jika abnormal return negatif menunjukkan terjadinya penurunan kemakmuran pemegang saham.

Beberapa peneltian yang sudah dilakukan menunjukkan hasil yang tidak konsisten. Penelitian yang dilakukan Allfian (2015), Wardhana (2017) dan Gusnita (2017) yang memperoleh hasil bahawa tidak terdapat perbedaan yang signifikan dari rasio-rasio kinerja keuangan dan abnormal return sebelum dan sesudah perusahaan melakukan akuisisi. Namun hasil yang berbeda diperoleh dari penelitian Andini (2015) dan Irawanto (2016) yang menyatakan hasil bahwa terdapat perbedaan yang signifikan dari rasio-rasio kinerja keuangan dan abnormal return sebelum dan sesudah perusahaan melakukan akuisisi.

Penelitian ini menggunakan rasio return on equity, current ratio, debt to equity, total aseet turnover, dan earning per share serta abnormal return. Dalam penelitian ini perusahaan yang akan dijadikan objek penelitian adalah perusahaan pengakuisisi, yang melakukan akuisisi di tahun 2014.

Berdasarkan inkonsisten hasil penelitian yang diperoleh dari penelitian sebelumnya dan berdasarkan latar belakang masalah yang telah dijabarkan, membuat peneliti tertarik untuk melakukan penelitian yang berjudul "Analisis Kinerja Keuangan dan Abnormal Return Sebelum dan Sesudah Akuisisi pada Perusahaan yang Terdaftar di Bursa Efek Indonesia Tahun 2014”.

Penelitian ini bertujuan untuk melihat apakah terdapat perbedaan kinerja keuangan dari aspek return on equity, current ratio, debt to equity, total asset turnover, dan earning per share serta abnormal return sebelum dan sesudah perusahan melakukan akuisisi. 


\section{Kajian Pustaka}

\section{Teori Sinyal (Signaling Theory)}

Teori sinyal merupakan sinyal informasi yang dibutuhkan oleh para investor untuk menentukan apakah investor tersebut akan menanamkan sahamnya pada perusahaan yang bersangkutan atau tidak. Teori sinyal menekankan kepada pentingnya informasi yang dikeluarkan oleh perusahaan terhadap keputusan investasi pihak luar perusahaan. Informasi yang dipublikasikan sebagai suatu pengumuman akan memberikan sinyal bagi investor dalam pengambilan keputusan investasi (Jogiyanto, 2016:398).

Teori sinyal dalam penelitian ini terkait dengan adanya informasi yang menjadi sinyal atau indikasi dari abnormal return dan aktivitas akuisisi suatu perusahaan terhadap investor dan pelaku pasar lainnya. Dengan adanya indikasi ini, maka investor dan pelaku pasar akan dapat menentukan sikapnya sebelum dan setelah adanya pengumuman terhadap suatu event. Prinsip signaling ini mengajarkan bahwa setiap tindakan mengandung informasi. Hal ini disebabkan karena adanya asymetric information. Asymmetric information adalah kondisi dimana suatu pihak memiliki informasi yang lebih banyak daripada pihak lain.

\section{Pengertian Akuisisi}

Akuisisi yaitu proses sebuah aset atau bisnis atau saham menjadi pemilik dari pembeli. Artinya, ada perpindahaan aset atau bisnis dari satu pihak ke pihak lain (Adler, 2011:16). PSAK No.22 Tahun 2015 tentang Kombinasi Bisnis mendefinisikan akuisisi sebagai suatu penggabungan usaha dimana salah satu perusahaan yaitu pengakuisisi mengambil alih perusahaan yang diakuisisi, sehingga akan mengakibatkan berpindahnya kendali atas perusahaan yang diambil alih tersebut. Biasanya perusahaan pengakuisisi memiliki ukuran yang lebih besar dibandingkan dengan perusahaan terakuisisi. Perusahaan yang bertindak sebagai pengakuisisi hanya mengambil alih kendali atas perusahaan yang diakuisisi. Kedua perusahaan masih tetap berdiri dan beroperasi secara independen, namun telah terjadi pengalihan oleh perusahaan pe ngakuisisi (Gustina, 2017).

\section{Metode Analisis Kinerja dengan Rasio Keuangan}

Analisis rasio keuangan adalah metode umum yang biasa digunakan perusahaan dalam mengukur kinerja perusahaan dalam bidang keuangan. Menurut (Harahap, 2011:190). Menurut Kasmir (2012:106) terdapat lima jenis rasio yang dapat digunakan untuk menilai kinerja keuangan perusahaan, yaitu:

1. Rasio profitabilitas

Rasio profitabilitas adalah rasio yang digunakan untuk menilai kemampuan perusahaan dalam mencari keuntungan, (Subramanyam, 2010:44). Dalam penelitian ini profitabilitas akan diproksikan dengan return on equity (ROE).

2. Rasio likuiditas

$$
R O E=\frac{\text { Laba }}{\text { Total Modal }}
$$

Rasio likuiditas adalah rasio yang menggambarkan kemampuan perusahaan dalam memenuhu kewajiban jangka pendeknya (Subramanyam, 2010:44). Dalam penelitian ini rasio likuiditas akan diproksikan dengan current ratio (CR).

\section{Rasio laverage}

$$
C R=\frac{\text { Current Asset }}{\text { Current Liabiities }}
$$

Rasio laverage atau biasa disebut dengan rasio solvabilitas adalah rasio yang digunakan untuk melihat sejauh mana asset perusahaan dibiayai dengan hutang (Kasmir, 2012:129). Dalam penelitian ini raso leverage akan diproksikan dengan debt to equity ratio (DER).

4. Rasio aktivitas

$$
D E R=\frac{\text { Total kewajiban }}{\text { Ekuitas pemegang saham }}
$$

Rasio aktivitas adalah ratio yang digunakan untuk mengukur efektivitas perusahaan dalam menggunakan asset yang dimiliki perusahaan (Subramanyam, 2010:44). Dalam penelitian ini raso leverage akan diproksikan dengan total asset turnover (TATO).

\section{Rasio pasar}

$$
\text { TATO }=\frac{\text { Penjualan }}{\text { Rata-rata total aset }}
$$

Rasio pasar adalah rasio yang mengukur seberapa besar nilai pasar saham perusahaan relative terhadap nilai bukunya (Kasmir, 2012:130). Dalam penelitian ini raso leverage akan diproksikan dengan earning per share (EPS).

$$
\mathrm{EPS}=\frac{\text { Laba }}{\text { Saham }}
$$




\section{Abnormal Return}

Meningkatnya aktivitas perdagangan saham yang disebabkan oleh berbagai peristiwa seperti penggabungan usaha, pengumuman deviden, atau menurunnya suku bunga, mengakibatkan terjadinya fluktuasi harga saham tersebut menjadi tinggi. Tingginya fluktuasi harga saham diharapkan diiringi dengan tingginya return saham yang akan diterima oleh investor (Wijanarko dan prasetiono, 2012). Return adalah tingkat keuntungan yang diperoleh investor atas investasi yang dilakukannya. Return saham dalam penelitian ini yaitu return saham yang abnormal (abnormal return).

Menurut Jogiyanto (2016:647) abnormal return merupakan kelebihan dari return yang sesungguhnya terjadi terhadap return normal. Abnormal return yaitu selisih antara tingkat keuntungan sebenarnya (actual return) dengan tingkat keuntungan yang diharapkan (expected return). Return actual atau return realisasi adalah return yang telah terjadi yang dihitung menggunakan data historis (Jogiyanto, 2016:648). Expected return adalah return yang diharapkan akan diperoleh di masa yang akan datang. Pada penelitian ini expected return menggunakan pendekatan market adjusted model. Abnormal return dapat dirumuskan sebagai berikut (Jogiyanto, 2016:649) :

Abnormal Return $A R_{i, t}$

$$
A R_{i, t}=R_{i, t}-R_{m, t}
$$

Actual Return $R_{i, t}$

$$
R_{i, t}=\frac{P_{i, t}-P_{i, t-1}}{P_{i, t-1}}
$$

Return pasar $R_{m, t}$

$$
R_{m, t}=\frac{I H S G_{t}-I H S G_{t-1}}{I H S G_{t-1}}
$$

Event window disebut juga window period atau waktu spesifik dimana suatu event terjadi dan diduga terdapat abnormal return di dalamnya. Window period ini digunakan untuk melihat reaksi padar dalam menanggapi suatu informasi, dalam penelitian ini yang digunakan yaitu 10 hari, dengan 5 hari sebelum pengumuman akuisisi dan 5 hari setelah pengumuman.

\section{Metode Penelitian Desain Penelitian}

Tujuan studi dalam penelitian ini adalah pengujian hipotesis. Studi yang termasuk dalam pengujian hipotesis biasanya menjelaskan sifat hubugan tertentu, atau menentukan perbedaan antar kelompok atau kebebasan (independensi) dua atau lebih faktor dalam suatu situasi (Sekaran, 2013:162). Tujuan penelitian ini yaitu untuk menentukan perbedaan kinerja keuangan dan abnormal return perusahaan 1 tahun sebelum dan 4 tahun sesudah melakukan akuisisi. Jenis investigasi dalam penelitian ini yaitu studi korelasional (correlational study).Studi kolerasional adalah studi yang dilakukan untuk menemukan hubungan penting suatu variabel berkaitan dengan masalah (sekaran, 2013:165).Penelitian ini menguji kinerja keuangan dan abnormal return perusahaan sebelum dan sesudah melakukan akuisisi. Dalam hal ini akan diketahui apakah kegiatan akuisisi berpengaruh terhadap kinerja keuangan dan abnormal return perusahaan.

Tingkat intervensi dalam penelitin ini adalah intervensi minimal dan situasi studi penelitian ini tidak diatur. Unit analisis dalam penelitian ini yaitu unit berpasangan. Data yang dikumpulkan dari penelitian ini adalah lapoan keuangan tahunan auditan dari perusahaan sebelum dan sesudah melakukan akuisisi. Dalam penelitian ini horizon waktu yang digunakan adalah studi longitudinal.

\section{Populasi dan Sampel Penelitian}

Populasi dalam penelitian ini merupakan populasi sasaran. Populasi sasaran adalah populasi spesifik yang relevan dengan tujuan masalah penelitian (Sekaran, 2013:122). Dalam penelitian ini populasi yang digunakan yaitu perusahaan yang melakukan akuisisi pada tahun 2014, sampel pada penelitian ditentukan dengan menggunakan metode purposive sampling. Kriteria sampel dalam penelitian ini adalah sebagai berikut :

1. Perusahaan yang melakukan akuisisi yang terdaftar di Bursa Efek Indonesia pada kurun waktu penelitian (2013-2017).

2. Perusahaan non keuangan.

3. Perusahaan yang laporan keuangannnya berakhir pada tanggal 31 Desember selama periode 2013 sampai dengan 2017. 
4. Tersedia laporan keuangan untuk satu tahun sebelum dan empat tahun setelah melakukan akuisisi pertama kali.

5. Tanggal akuisisi diketahui dengan jelas

Menurut laporan tahun KPPU terdapat 53 perusahaan yang melakukan akuisis pada tahun 2014 . Berdasarkan kriteria yang telah disebutkan, didapat sampel sebanyak 10 perusahaan dari 53 perusahaan tersebut.

\section{Sumber Data dan Tekni Pengumpulan Data}

Data yang digunakan pada penelitian ini merupakan data yang berbentuk sekunder yang dikumpulkan dan diolah berasal dari laporan keuangan perusahaan yang terdaftar di bursa efek Indonesia. Data yang diperlukan yaitu daftar perusahaan yang melakukan akuisisi pada tahun 2014 yang dapat diperoleh dari situs www.kppu.go.id. Rasio tahunan (ikhtisar keuangan) laporan arus kas serta laporan laba rugi dapat di akses dari web.idx.id, dan harga saham harian beserta IHSG (Indeks Harga Saham Gabungan) yang terdapat di yahoo.finance.com. Teknik pengumpulan data dilakukan dengan cara dokumentasi.

\section{Metode Analisis}

Metode analisis yang digunakan untuk menguji hipotesis adalah uji beda (t-test). Untuk menguji H1H6 akan digunakan wilcoxon sign ranks test dan paired sample t-test. Wilcoxon sign ranks test dan paired sample t-test digunakan untuk membandingkan dua kelompok rata-rata dari dua sampel yang berbeda.:

1. Merumuskan hipotesis.

2. Melakukan uji normalitas Kolmogrov-Smirnov

3. Melakukan uji beda Paired Sample T Test dan Wilcoxon Signed Ranks Test.

4. Menentukan kriteria penerimaan dan penolakan hipotesis:

Jika stastistik dengan nilai signifikasi $<5 \%$ maka Hipotesis diterima, artinya terdapat perbedaan secara signifikan.

Jika stastistik dengan nilai signifikasi > 5\% maka Hipotesis ditolak, artinya tidak terdapat perbedaan secara signifikan.

\section{Hasil dan Penelitian Statistik Deskritif}

Statistik deskriptif bertujuan untuk menggambarkan data mentah yang dianalisis dalam penelitian ini. Gambaran dari keseluruhan variabel yang diuji dapat dilihat pada tabel statistik yang menyajikan data nilai mean dan standar deviasi setiap variabel yang diuji.

\section{Analisis Data}

Analiasis data pada penelitian ini dimulai dengan menguji normalitas data sampel perusahaan. Uji normalitas ini dilakukan untuk menentukan alat uji hipotesis yang akan digunakan untuk menguji sampel penelitian. Jika sampel penelitian terdistribusi normal maka akan digunakan uji parametrik yaitu dengan paired sample $\mathrm{t}$ test, namun jika sampel penelitian tidak terdistribusi normal, maka akan digunakan uji nonparametrik yaitu dengan uji Wilcoxon Sign Rank Test.

\section{Uji Normalitas Data}

Pada penelitian ini, data dikatakan berdistribusi normal apabila Asymptotic sig > taraf signifikan (tingkat kepercayaan) yang digunakan dalam pengujian (tingkat kepercayaan 95\% atau $\alpha=0,05$ ). Sebaliknya sampel dikatakan tidak berdistribusi normal apabila Asymptotic sig < taraf signifikan. Hasil uji normalitas data sampel menggunakan uji Kolmogorov-Smirnov. Jika data berdistribusi normal maka metode pengujian hipotesis menggunakan uji paired sample t-test, namun jika data tidak berdistribusi normal maka pengujian hipotesis menggunakan uji wilcoxon signed ranks test. Berikut rekapitulasi hasil uji normalitas variable dan metode pengujian variabel.

Tabel 4.1

Metode Pengujian Variabel

\begin{tabular}{|c|c|c|c|}
\hline Variabel & $\begin{array}{c}\text { Hasil Uji } \\
\text { Normalitas } \\
\text { Data }\end{array}$ & Statistik & Uji Hipotesis \\
\hline ROA & Normal & Parametrik & Paired Sample T \\
\hline CR & Normal & Parametrik & Paired Sample T \\
\hline DER & Normal & Parametrik & Paired Sample T \\
\hline TATO & Normal & Parametrik & Paired Sample T \\
\hline EPS & Normal & Parametrik & Paired Sample T \\
\hline AR & $\begin{array}{c}\text { Normal/Tidak } \\
\text { Normal }\end{array}$ & $\begin{array}{c}\text { Non } \\
\text { Parametrik }\end{array}$ & $\begin{array}{c}\text { Wilcoxon Sign } \\
\text { Rank Test }\end{array}$ \\
\hline
\end{tabular}

Sumber : Data Diolah (2018) 


\section{Uji Hipotesis}

1. Pengujian Periode Satu Tahun Sebelum dan Satu Sesudah Akuisisi

Tabel 4.2

Hasil Uji Paired Sample T-Test

\begin{tabular}{|c|c|c|c|c|}
\hline Hipotesis & Variabel & Prob & $\boldsymbol{\alpha}$ & Kesimpulan \\
\hline H1 & ROE & 0,241 & 0,05 & $\begin{array}{c}\text { Tidak } \\
\text { Berbeda }\end{array}$ \\
\hline H2 & CR & 0,963 & 0,05 & $\begin{array}{c}\text { Tidak } \\
\text { Berbeda }\end{array}$ \\
\hline H3 & DER & 0,171 & 0,05 & $\begin{array}{c}\text { Tidak } \\
\text { Berbeda }\end{array}$ \\
\hline H4 & TATO & 0,251 & 0,05 & $\begin{array}{c}\text { Tidak } \\
\text { Berbeda }\end{array}$ \\
\hline H5 & EPS & 0,573 & 0,05 & $\begin{array}{c}\text { Tidak } \\
\text { Berbeda }\end{array}$ \\
\hline
\end{tabular}

Sumber : Data Diolah (2018)

Berdasarkan hasil uji beda yang telah dilakukan tersebut, pada rasio ROE, CR, DER, TATO, dan EPS memiliki nilai Asymp. Sig. > nilai signifikansi (0.05). Hal ini menunjukkan tidak terdapat perbedaan kinerja perusahaan antara periode satu tahun sebelum dan satu tahun sesudah melakukan.

2. Pengujian Periode Satu Tahun Sebelum dan Dua Sesudah Akuisisi

Tabel 4.3

Hasil Uji Paired Sample T-Test

\begin{tabular}{|c|c|c|c|c|}
\hline Hipotesis & Variabel & Prob & $\alpha$ & Kesimpulan \\
\hline H1 & ROE & 0,346 & 0,05 & $\begin{array}{c}\text { Tidak } \\
\text { Berbeda }\end{array}$ \\
\hline $\mathrm{H} 2$ & CR & 0,405 & 0,05 & $\begin{array}{c}\text { Tidak } \\
\text { Berbeda }\end{array}$ \\
\hline H3 & DER & 0,123 & 0,05 & $\begin{array}{c}\text { Tidak } \\
\text { Berbeda }\end{array}$ \\
\hline $\mathrm{H} 4$ & TATO & 0,045 & 0,05 & Berbeda \\
\hline H5 & EPS & 0,799 & 0,05 & $\begin{array}{c}\text { Tidak } \\
\text { Berbeda }\end{array}$ \\
\hline
\end{tabular}

Sumber : Data Diolah (2018)

Berdasarkan hasil uji beda yang telah dilakukan tersebut, pada rasio ROE, CR, DER, dan EPS memiliki nilai Asymp. Sig. > nilai signifikansi (0.05). Hal ini menunjukkan tidak terdapat perbedaan kinerja perusahaan antara periode satu tahun sebelum dan dua tahun sesudah melakukan akuisisi pada rasio ROE, CR, DER dan EPS. Namun pada rasio TATO memiliki nilai Asymp. Sig. < nilai signifikansi (0.05), artinya terdapat perbedaan pada rasio TATO periode satu tahun sebelum dan satu dua tahun sesudah akuisisi.
3. Pengujian Periode Satu Tahun Sebelum dan Tiga Sesudah Akuisisi

Tabel 4.4

Hasil Uji Paired Sample T-Test

\begin{tabular}{|c|c|c|c|c|}
\hline Hipotesis & Variabel & Prob & A & Kesimpulan \\
\hline H1 & ROE & 0,440 & 0,05 & $\begin{array}{c}\text { Tidak } \\
\text { Berbeda }\end{array}$ \\
\hline H2 & CR & 0,514 & 0,05 & $\begin{array}{c}\text { Tidak } \\
\text { Berbeda }\end{array}$ \\
\hline H3 & DER & 0,313 & 0,05 & $\begin{array}{c}\text { Tidak } \\
\text { Berbeda }\end{array}$ \\
\hline H4 & TATO & 0,058 & 0,05 & $\begin{array}{c}\text { Tidak } \\
\text { Berbeda }\end{array}$ \\
\hline H5 & EPS & 0,487 & 0,05 & $\begin{array}{c}\text { Tidak } \\
\text { Berbeda }\end{array}$ \\
\hline
\end{tabular}

Sumber : Data Diolah(2018)

Berdasarkan hasil uji beda yang telah dilakukan tersebut, pada rasio ROE, CR, DER, TATO, dan EPS memiliki nilai Asymp. Sig. > nilai signifikansi (0.05). Hal ini menunjukkan tidak terdapat perbedaan kinerja perusahaan antara periode satu tahun sebelum dan tiga tahun sesudah melakukan akuisisi.

4. Pengujian Periode Satu Tahun Sebelum dan Empat Sesudah Akuisisi

Tabel 4.5

Hasil Uji Paired Sample T-Test dan Wilcoxon Sign Ranks Test

\begin{tabular}{|c|c|c|c|c|}
\hline Hipotesis & Variabel & Prob & $\boldsymbol{\alpha}$ & Kesimpulan \\
\hline H1 & ROE & 0,281 & 0,05 & $\begin{array}{c}\text { Tidak } \\
\text { Berbeda }\end{array}$ \\
\hline H2 & CR & 0,745 & 0,05 & $\begin{array}{c}\text { Tidak } \\
\text { Berbeda }\end{array}$ \\
\hline H3 & DER & 0,191 & 0,05 & $\begin{array}{c}\text { Tidak } \\
\text { Berbeda }\end{array}$ \\
\hline H4 & TATO & 0,028 & 0,05 & Berbeda \\
\hline H5 & EPS & 0,601 & 0,05 & $\begin{array}{c}\text { Tidak } \\
\text { Berbeda }\end{array}$ \\
\hline
\end{tabular}

Sumber : Data Diolah (2018)

Berdasarkan hasil uji beda yang telah dilakukan tersebut, pada rasio ROE, CR, DER, dan EPS memiliki nilai Asymp. Sig. > nilai signifikansi (0.05). Hal ini menunjukkan tidak terdapat perbedaan kinerja perusahaan antara periode satu tahun sebelum dan dua tahun sesudah melakukan akuisisi pada rasio ROE, CR, DER dan EPS. Namun pada rasio TATO memiliki nilai Asymp. Sig. < nilai signifikansi (0.05), artinya terdapat perbedaan pada rasio TATO pada periode satu tahun sebelum dan empat tahun sesudah akuisisi. 
5. Pengujian Periode Sebelum dan Sesudah Akuisisi Pada Abnormal Return

Tabel 4.6

Hasil Uji Wilcoxon Sign Ranks Test

\begin{tabular}{|c|c|c|c|c|}
\hline Hipotesis & Variabel & Prob & $\boldsymbol{\alpha}$ & Kesimpulan \\
\hline H6 & AR & 0,721 & 0,05 & $\begin{array}{c}\text { Tidak } \\
\text { Berbeda }\end{array}$ \\
\hline
\end{tabular}

Sumber : Data Diolah (2018)

Berdasarkan hasil uji beda yang telah dilakukan tersebut, pada abnormal return memiliki nilai Asymp. Sig. > nilai signifikansi (0.05). Hal ini menunjukkan tidak terdapat perbedaan abnormal return antara sebelum dan sesudah melakukan akuisisi.

\section{Pembahasan}

Hasil pengujian hipotesis dengan taraf signifikansi 5\%(0.05) menunjukkan bahwa rasio keuangan yang diuji tidak terdapat perbedaan yang signifikan antara sebelum dan sesudah melakukan akuisisi. Namun pada rasio TATO tahun kedua dan keempat terdapat perbedaan yang siginifikan setelah melakukan akuisisi, yang mana pada tahun pertama dan tahun ketiga tidak menunjukkan perbedaan. Adanya perbedaan yang signifikan pada rasio TATO pada tahun kedua dan keempat ini menunjukkan bahwa meningkatnya kemampuan asset perusahaan dalam menghasilkan pendapatan. Pada variabel abnormal return juga tidak terdapat perbedaan antara sebelum dan sesudah perusahaan melakukan akuisisi. Berikut hasil rekapitulasi uji variabel dijelaskan pada tabel 4.7

Tabel 4.7

Rakapitulasi Hasil Uji Beda Variabel

\begin{tabular}{|c|c|c|c|c|c|}
\hline \multirow{2}{*}{ Var } & \multirow{2}{*}{ Tahun } & \multicolumn{4}{|c|}{ Hasil Uji Beda Variabel } \\
\cline { 3 - 6 } & & $\mathbf{1}$ & $\mathbf{2}$ & $\mathbf{3}$ & $\mathbf{4}$ \\
\hline ROE & 1 & Tidak Berbeda & Tidak Berbeda & Tidak Berbeda & Tidak Berbeda \\
\hline CR & 1 & Tidak Berbeda & Tidak Berbeda & Tidak Berbeda & Tidak Berbeda \\
\hline DER & 1 & Tidak Berbeda & Tidak Berbeda & Tidak Berbeda & Tidak Berbeda \\
\hline TATO & 1 & Tidak Berbeda & Berbeda & Tidak Berbeda & Berbeda \\
\hline EPS & 1 & Tidak Berbeda & Tidak Berbeda & Tidak Berbeda & Tidak Berbeda \\
\hline AR & 1 & Tidak Berbeda & Tidak Berbeda & Tidak Berbeda & Tidak Berbeda \\
\hline
\end{tabular}

Sumber: Data Diolah (2018

Pengujian hipotesis untuk rasio keuangan profitabilitas yang diproyeksikan dengan Return On Equity (ROE) menunjukkan hasil bahwa tidak terdapat perbedaan yang signifikan antara sebelum dan sesudah melakukan akuisisi, baik untuk satu tahun sampai empat tahun sesudah akuisisi. Hasil dari penelitian ini tidak sesuai dengan teori yang dikemukakan oleh Subramanyam, (2010:359) bahwa penggabungan usaha dapat meningktakan citra perusahaan, potensi pertumbuhan, kesejahteraan perusahaan dan untuk meningktkan laba. Akuisisi akan berdampak positif jika perusahaan pengakuisisi memiliki modal dan kinerja keuangan yang baik. Maka ROE perusahaan yang tidak berbeda antara sebelum dan sesudah akuisisi menunjukkan bahwa kemampuan modal sendiri perusahaan untuk menghasilkan laba dari setiap aktivitasnya menurun. Ini bisa saja terjadi menurut Payamta (2004) yang menjelaskan bahwa dalam melakukan akuisisi membutuhkan biaya yang tidak sedikit dan modal yang relatif banyak, sehingga perusahaan tidak bisa memaksimalkan laba yang diperolehnya setelah akuisisi. Hasil penelitian ini sejalan dengan penelitian yang dilakukan oleh (Oktaviani, 2015), sehingga disimpulakan rasio profitabilitas tidak berbeda secara signifikan antara sebelum dan sesudah akuisisi (H1 tidak diterima).

Rasio likuiditas pada penelitian ini diukur dengan menggunakan current ratio (CR). Hasil uji beda penelitian ini menunjukkan bahwa tidak terdapat perbedaan yang signifikan antara sebelum dan sesudah perushaan melakukan akuisisi, baik satu tahun sesudah akuisisi hingga empat tahun sesudah akuisisi. Tidak terdapatnya perbedaan pada CR ini disebabkan oleh meningkatnya hutang lancar perusahaan yang tidak diimbangi oleh asset lancar perusahaan, sehingga mengakibatkan menurunnya CR. Berdasarkan data yang diperoleh, hutang lancar dan aset lancar perusahaan cenderung konstan setiap tahunnya 
meskipun sudah dilakukan akuisisi. Dengan dilakukannya akuisisi maka aset lancar perusahaan digabungkan, seharusnya kemampuan perusahaan untuk memenuhi kewajiban jangka pendeknya semakin baik, yang ditunjukkan dengan adanya perbedaan signifikan, namun karena hasilnya tidak menunjukkan adanya perbedaan yang signifikan setelah akuisisi, berarti bisa dikatakan bahwa tujuan akuisisi untuk mencapai sinergi belum tercapai. Hasil penelitian ini sejalan dengan penelitian yang dilakukan oleh (Tarigan dan pratomo, 2016), yang menyatakan bahwa tidak terdapat perbedaab yang signifikan antara sebelum dan sesudah akusisi pada current ratio. Oleh karena itu disimpulkan bahwa rasio likuiditas tidak berbeda secara signifikan antara sebelum dan sesudah akuisisi (H2 tidak diterima).

Rasio leverage pada penelitian ini menggunakan rasio deb to equity (DER). Hasil penelitian menunjukkan bahwa tidak terdapat perbedaan antara sebelum dan sesudah perusahaan melakukan akuisisi, baik satu tahun sesudah sampai empat tahun sesudah melakukan akuisisi. Hal ini menunjukan bahwa perusahaan belum bisa dikatakan mampu untuk membayar hutang seluruh perusahaan dan mengalami kesulitan untuk memaksimalkan modal sendiri. Berarti modal sendiri masih belum cukup untuk menjamin atau melunasi hutang perusahaan karena hutang perusahaan lebih tinggi daripada ekuitas perusahaan. Hutang yang terlalu tinggi kemungkinan perusahaan lebih banyak menggunakan dana untuk pembiayaan operasi pasca akuisisi. Hal ini sesuai dengan teori yang dikemukakan oleh Moin (2010:141) penggunaan hutang yang terlalu besar akan mempertinggi kemungkinan perusahaan tidak bisa mengembalikan hutang karena harus membayar angsuran dan bunga tetap. Hasil penelitian ini sejalan dengan penelitian yang dilakukan oleh (Tarigan dan pratomo, 2016), yang menyatakan bahwa tidak tedpat perbedaan signifikan pada rasio debt to equity antar sebelum dan sesudah melakukan akuisisi. Dapat disimpulkan bahwa rasio leverage tidak berbeda secara signifikan antara sebelum dan sesudah akuisisi (H3 tidak diterima).

Rasio aktivitas pada penelitian ini diukur dengan total asset turnover (TATO). Hasil penelitian ini menunjukkan tidak terdapat perbedaan yang signifikan antara sebelum dan sesudah melakukan akuisisi pada tahun pertama dan tahun ketiga sesudah akuisisi. Tidak terdapatnya perbedaan ditahun pertama disebabkan karena kegiatan akuisisi dilakukan perusahaan patahun tersebut, sehingga ditahun ini belum banyak terdapaat perbedaan rasio keuangan dibandingkan dengan tahun sebelum akuisisi. Namun pada tahun kedua dan keempat setelah akuisisi menunjukkan adanya perbedaan yang signifikan. Hasil penelitian ini sejalan dengan penelitian yang dilakukan oleh (Hasanah dan Oktaviani, 2017), hasil penelitian tersebut menyatakan bahwa terdapat perbedaan signifikan pada rasio total asset turnover antara sebelum dan setelah akuisisi. Dapat disimpulkan bahwa rasio aktivitas berbeda secara signifikan antara sebelum dan sesudah akuisisi (H4 diterima).

Untuk mengukur rasio pasar pada penelitian ini menggunakan earning per share (EPS). Rasio ini menunjukkan hasil bagi antara laba bersih dengan jumlah saham yang beredar. Hasil penelitian ini menunjukkan bahwa tidak terdapat perbedaan EPS antara sebelum dan sesudah perusahaan melakukan akuisisi, baik pada satu tahun sesudah akuisisi sampai empat tahun sesudah perusahaan melakukan akuisisi. Hal ini berbanding lurus dengan hasil yang diperoleh dari rasio ROE yang menjadi komponen penilaian EPS itu sendiri, yang mana EPS dan ROE sama-sama mengacu pada laba setelah pajak. (Kasmir, 2012). Tidak adanya perbedaan EPS secara signifikan menunjukkan bahwa terjadi penurunan terhadap laba perusahaan setelah akuisisi, dengan dimikian tujuan investor untuk mendapatkan laba per lembar saham yang lebih besar dari proses akuisisi tidak dapat diterima. Hasil penelitian ini sejalan dengan penelitian yang dilakukan oleh (Hasanah dan Oktaviani, 2017), yang menyatakan bahwa tidak terdapat perbedaan signifikan pada rasio earning per share antara sebelum dan sesudah akuisisi. Dapat disimpulkan bahwa rasio pasar tidak berbeda secara signifikan antara sebelum dan sesudah akuisisi (H5 tidak diterima).

Pengujian hipotesis untuk abnormal return yang diuji dengan Wilcoxon Sign Rank Test pada periode estimasi 5 hari sebelum dan 5 hari sesudah akuisis. Hasil penelitian ini menunjukkan bahwa tidak terdapat perbedaan yang signifikan antara sebelum dan sesudah perusahaan melakukan akuisisi. Abnormal return setelah akuisisi lebih rendah atau sama dengan abnormal return perusahaan sebelum akuisisi. Hal ini disebabkan karena peningkatan harga saham sesudah akuisisi tidak cukup tinggi dibandingkan dengan harga saham sebelum akuisisi. Pada penelitian ini 
menunjukkan bahwa selama periode estimasi terdapat rata-rata abnormal return yang kurang konsisten dan pada periode setelah peristiwa. Terjadi kenaikan dan penurunan saham namun tidak signifikan mengindikasikan para investor beranggapan bahwa pengumuman akuisisi sebagai sebuah informasi buruk yang tidak dapat memberikan prospek perusahaan yang baik di masa mendatang. Andini. et al, 2015 menyatakan bahwa adanya abnormal return yang tidak berbeda setelah pengumuman akuisisi dilakukan juga dapat disebabkan karena bocornya informasi akuisisi perusahaan, sehingga pasar tidak terkejut saat pengumuman akuisisi tersebut disekitar tanggal pengamatan. Hasil penelitian ini sejalan dengan penelitian yang dilakukan oleh (Tarigan dan pratomo, 2016), yang menyatakan bahwa tdak terdapat perbedaan pada abnormal retrn antara sebelumd an sesudah akuisisi. Dapat disimpulkan abnormal return tidak berbeda secara signifikan antara sebelum dan sesudah akuisisi (H6 tidak diterima).

\section{Kesimpulan, Keterbatasan dan Saran}

Berdasarkan hasil penelitian mengenai analisis perbandingan kinerja keuangan perusahaan dan abnormal return sebelum dan sesudah akuisisi, maka dapat diambil kesimpulan sebagai berikut:

1. Tidak terdapat perbedaan yang signifikan pada rasio profitabilitas antara satu tahun sebelum dan empat tahun sesudah akuisisi.

2. Tidak terdapat perbedaan yang signifikan pada rasio likuiditas antara satu tahun sebelum dan empat tahun sesudah akuisisi.

3. Tidak terdapat perbedaan yang signifikan pada rasio leverage antara satu tahun sebelum dan lima dan empat tahun sesudah akuisisi.

4. Tidak terdapat perbedaan yang signifikan pada rasio aktivitas antara satu tahun sebelum dan tiga tahun sesudah akuisisi. Namun pada periode dua tahun dan empat tahun sesudah akuisisi terdapat perbedaan yang signifikan.

5. Tidak terdapat perbedaan yang signifikan pada rasio pasar antara satu tahun sebelum dan dan empat tahun sesudah akuisisi.

Adapun keterbatasan dalam penelitian ini adalah sebagai berikut.

1. Penelitian ini hanya dilakukan dengan menganalisis kinerja keuangan perusahaan menggunakan rasio-rasio keuangan. Namun banyak faktor non ekonomi yang mempengaruhi kinerja keuangan perusahaan seperti sumber daya perusahaan, faktor teknologi dan budaya yang ada pada perusahaan.

2. Kurangnya variabel-variabel yang mewakili rasio keuangan perusahaan dan kurang lamanya periode pengamatan pada variabel abnormal return yang digunakan peneliti.

\section{Daftar Pustaka}

Adler, H. (2011). Restrukturisasi Perusahaan: Merger, Akuisisi dan Konsolidasi, Serta Pembiayaan. Jakarta: Stiep Press.

Allfian, Ayu Dwi dan Triyonowati. (2015). Analisis Perbedaan Kinerja Keuangan Sebelum dan Sesudah Akuisisi pada Pt.Jasa Marga,Tbk. Jurnal Ilmu dan Riset Manajemen. Vol. 4. No. 12.

Andini , Dwi Ari, R. Rustam Hidayat dan Sri Sulasmiyati. (2015). Analisis Perbandingan Return On Investment (Roi), Earning Per Share (Eps), Dan Abnormal Return Perusahaan Sebelum dan Sesudah Merger dan Akuisisi. Jurnal Administrasi Bisnis. Vol. 27 No. 2.

Febyanti, Shabrina. (2014). Analisisi Rekasi Pasar Sebelum dan Sesudah Pengumuman Akuisisi Pt. Hanjaya Mandala Sampoerna Tbk. Jurnal Ilmu Manajemen. Vol. 2. No 1.

Gustina, Ira. (2017). Analisis Kinerja Keuangan Sebelum dan Sesudah Merger dan Akuisisi pada Perusahaan yang Go Public yang Terdaftar di BEI. Jurnal Akuntansi Dan Keuangan. Vol. 6. No 2. ISSN. 2598-7372.

Harahap, Sofyan Syafri. (2011). Analisis Kritis Atas Laporan Keuangan. Jakarta: Pt Rajawali Grafindo.

Hasanah, Ade Nahdiatul dan Trisna Maya Oktaviani. (2017). Analisis Kinerja Perusahaan dan Abnormal Return Saham Sebelum dan Sesudah Akuisisi, Jurnal Akuntansi. Vol. 4. No. 2. ISSN. 2339-2436.

Hunger J.D dan Wheelen T.L. (2012). Strategic Management And Bussiness Policy: Toward Global Sustainability. $13^{\text {th }}$. New York: Pearson.

Irawanto, Danang Bayu dan Tri Yuniati, (2016). Analisis Kinerja Keuangan Sebelum dan Sesudah Akuisisi Pt. Bank Rakyat Indonesia Tbk. Sekolah Tinggi Ilmu Ekonomi Indonesia. Vol. 5 No 1. ISSN : 2461-0593.

Jogiyanto, Hartono. (2016). Teori Portofolio dan Analisis Investasi. Edisi Kesepuluh. Yoyakarya: Bpfe.

Kasmir, (2012). Analisis Laporan Keuangan. Jakarta : Pt. Raja Grafindo Persada. 
Moin, Abdul. (2010). Merger, Akuisisi dan Divestasi. Edisi Kedua. Yogyakarta: Ekonisia.

Oktaviani, Anria Gusnelly dan Budi Rustandi Kartawinata. (2015). Analisis Perbedaan Kinerja Keuangan Perusahaan Sebelum Dan Sesudah Akuisisi Pada Perusahaan Yang Terdaftar Di Bursa Efek Indonesia Tahun 2011. EProceeding of Management. Vol. 2. No. 2. ISSN. 2355-9357.

Sekaran Uma dan Roger Bougie, (2013). Research Methods For Business. A Skill Building Approach $6^{\text {th }}$ Edition. New York: John Willey and Sons Ltd.

Subramanyam, K. R. dan Jhon J. Wild, (2010). Analisis Laporan Keuangan. Penerjemah Dewi Y. Jakarta: Salemba Empat.

Tarigan, Pivi Princifal Y. dan Pratomo Wahyu Ario. (2016). Analisis Dampak Merger Dan Akuisisi Terhadap Abnormal Return Dan Kinerja Keuangan Pada Perusahaan Yang Terdaftar Di Bursa Efek Indonesia. Jurnal Ekonomi dan Keuangan. Vol. 3. N0. 3.

Wardhana, Ega Eri dan Tri Yuniati. (2017). Analisis Profitabilitas dan Abnormal Return Sebelum dan Sesudah Akuisisi Pt Astra Otoparts Tbk. Jurnal Ilmu dan Riset Manajemen. Vol. 6. No 2. Issn : 2461-0593.

Wijanarko Iguh dan Prasetiono. (2012). Analisis Pengaruh Pemecahan Saham (Stock Split) Terhadap Likuiditas Saham dan Return Saham (Study Kasus pada Perusahaan yang Terdaftar BEI Periode 2007-2011). Diponogoro Jurnal Of Management.

Melani Agustina. (2018). Aksi Merger dan Akuisisi Global Cetak Rekor Pada Kuartal I. Melalui (Http://Liputan6.com). Diakses Pada 3 Maret 2018. 